\title{
Genetic diversity of Ralstonia solanacearum as assessed by PCR-RFLP of the hrp gene region, AFLP and 16S rRNA sequence analysis, and identification of an African subdivision
}

\author{
Stéphane Poussier, ${ }^{1}$ Danielle Trigalet-Demery, ${ }^{2}$ Peggy Vandewalle, ${ }^{1}$ \\ Bruno Goffinet, ${ }^{3}$ Jacques Luisetti ${ }^{1}$ and André Trigalet $^{2}$
}

Author for correspondence: Stéphane Poussier. Tel: +332623576 30. Fax: +33262 357641 . e-mail: poussier@cirad.fr

1 Laboratoire de

Phytopathologie, CIRAD-

FLHOR, 97448 Saint-Pierre

Cedex, La Réunion, France

2 Laboratoire de Biologie Moléculaire des Relations Plantes-Microorganismes, INRA-CNRS, BP27, 31326 Castanet-Tolosan Cedex, France

3 Unité de Biométrie et d'Intelligence Artificielle, INRA, BP27, 31326

Castanet-Tolosan Cedex, France

\begin{abstract}
The genetic diversity among strains in a worldwide collection of Ralstonia solanacearum, causal agent of bacterial wilt, was assessed by using three different molecular methods. PCR-RFLP analysis of the hrp gene region was extended from previous studies to include additional strains and showed that five amplicons were produced not only with all $R$. solanacearum strains but also with strains of the closely related bacteria Pseudomonas syzygii and the blood disease bacterium (BDB). However, the three bacterial taxa could be discriminated by specific restriction profiles. The PCR-RFLP clustering, which agreed with the biovar classification and the geographical origin of strains, was confirmed by AFLP. Moreover, AFLP permitted very fine discrimination between different isolates and was able to differentiate strains that were not distinguishable by PCR-RFLP. AFLP and PCR-RFLP analyses confirmed the results of previous investigations which split the species into two divisions, but revealed a further subdivision. This observation was further supported by 165 rRNA sequence data, which grouped biovar 1 strains originating from the southern part of Africa.
\end{abstract}

Keywords: bacterial wilt, PCR-RFLP, hrp, AFLP, 16S rRNA

\section{INTRODUCTION}

Ralstonia solanacearum causes bacterial wilt of a wide range of crops (potato, tomato, tobacco, banana, ginger, peanut, etc.) and is one of the most important plant diseases in tropical, subtropical and warm temperate regions of the world (Hayward, 1991). R. solanacearum shows great phenotypic and genotypic diversity, usually being divided into five races based on host range (Buddenhagen et al., 1962; He et al., 1983; Pegg \& Moffett, 1971) and six biovars based on biochemical properties (Hayward, 1964; Hayward et al., 1990; He et al., 1983). The use of RFLP (Cook et al., 1989; Cook \& Sequeira, 1994) allowed division of the species into two groups correlated with the geographical origin of

Abbreviations: AFLP, amplified fragment length polymorphism; $B D B$, blood disease bacterium; HCA, hierarchical cluster analysis; UPGMA, unweighted pair group method with arithmetic averages.

The GenBank accession numbers for the sequences determined in this work are AF207891-AF207897. strains: the 'Americanum' division contains biovar 1, 2 and N2 strains whereas the 'Asiaticum' division comprises biovars 3, 4 and 5 strains. Sequence analysis of the 16S rRNA gene (Li et al., 1993; Seal et al., 1993; Taghavi et al., 1996), the 16S-23S rRNA gene intergenic spacer region, the polygalacturonase gene and the endoglucanase gene (Fegan et al., 1998) have confirmed the two divisions and revealed a further subdivision including Indonesian isolates.

However, recent PCR-RFLP analysis of the hrp gene region (Poussier et al., 1999), including many African strains, which were rarely included in previous analyses of the genetic diversity of $R$. solanacearum, was not totally consistent with the above classification scheme since an African biovar 1 strains group belonged to the 'Asiaticum' division instead of the 'Americanum' division. Therefore, to clarify the relationships between these biovar 1 strains originating from the Southern part of Africa and other $R$. solanacearum isolates, three different approaches were compared and are presented 
Table 1. R. solanacearum, P. syzygii, R. pickettii and the BDB strains used in this study

\begin{tabular}{|c|c|c|c|c|c|c|}
\hline Strain* & $\begin{array}{c}\text { Other } \\
\text { designation } †\end{array}$ & $\begin{array}{l}\text { Biovar or } \\
\text { taxon }\end{array}$ & $\begin{array}{l}\text { PCR-RFLP } \\
\text { cluster and } \\
\text { subcluster }\end{array}$ & $\begin{array}{l}\text { AFLP cluster } \\
\text { and profile } \neq\end{array}$ & Geographical origin & Host \\
\hline JS796 & CFBP 1180 & 1 & Ia & I 1 & Puerto Rico & Lycopersicon esculentum \\
\hline JS927 & NCBBP 1225 & 1 & Ia & & Puerto Rico & Lycopersicon esculentum \\
\hline JS833 & UW30 & 1 & Ia & & Trinidad and Tobago & Lycopersicon esculentum \\
\hline JR659 & CFBP 2047 & 1 & $\mathrm{Ib}$ & I 2 & United States & Lycopersicon esculentum \\
\hline JS783 & CFBP 1036 & 1 & $\mathrm{Ib}$ & & United States & Lycopersicon esculentum \\
\hline JT645 & UW27 & 1 & $\mathrm{Ib}$ & & United States & Nicotiana tabacum \\
\hline JS967 & ICMP 7963 & 1 & $\mathrm{Ib}$ & I 3 & Kenya & Solanum tuberosum \\
\hline JS831 & UW26 & 1 & Ic & I 4 & United States & Lycopersicon esculentum \\
\hline JS716 & CFBP 705 & 1 & IIa & & Guyana & Lycopersicon esculentum \\
\hline JS733 & CFBP 2478 & 1 & IIa & II 6 & Guadeloupe & Lycopersicon esculentum \\
\hline JS734 & CFBP 2972 & 1 & IIa & II 7 & Martinique & Solanum tuberosum \\
\hline JS768 & CFBP 767 & 1 & IIa & & Guadeloupe & Solanum tuberosum \\
\hline JS777 & CFBP 770 & 1 & IIa & & Guadeloupe & Lycopersicon esculentum \\
\hline JS784 & CFBP 1036 & 1 & IIa & & Martinique & Lycopersicon esculentum \\
\hline JS794 & CFBP 1162 & 1 & IIa & & Guadeloupe & Nicotiana tabacum \\
\hline JS837 & UW90 & 1 & IIa & & Brazil & Nicotiana tabacum \\
\hline JS838 & UW275 & 1 & IIa & II 8 & Costa Rica & $\begin{array}{l}\text { Melampodium } \\
\text { perfoliatum }\end{array}$ \\
\hline JS830 & UW256 & 1 & IIa & & Costa Rica & Solanum tuberosum \\
\hline JS779 & CFBP 715 & 1 & IIa & II 9 & Burkina Faso & Lycopersicon esculentum \\
\hline JS912 & CFBP 3057 & 1 & IIa & & Burkina Faso & Lycopersicon esculentum \\
\hline JS770 & CFBP 712 & 1 & IIa & II 10 & Burkina Faso & Solanum melongena \\
\hline JS845 & CFBP 1175 & 1 & IIa & & Trinidad and Tobago & Solanum melongena \\
\hline JS903 & CFBP 3104 & 1 & IIa & & Peru & Solanum tuberosum \\
\hline JT649 & UW181 & 1 & IIa & II 11 & Venezuela & Musa sp. cv. plantain \\
\hline JT652 & UW469 & 1 & $\mathrm{IIb}$ & & Brazil & Solanum tuberosum \\
\hline JS740 & CFBP 1415 & 1 & III & III 12 & Colombia & Solanum tuberosum \\
\hline JS788 & CFBP 1412 & 1 & III & & Colombia & Musa sp. cv. plantain \\
\hline JS847 & CFBP 1419 & 1 & III & & Costa Rica & Musa sp. \\
\hline JT648 & UW162 & 1 & III & III 13 & Peru & Musa sp. cv. plantain \\
\hline JT509 & & 2 & $\mathrm{IVa}$ & IV 16 & Reunion Island & Lycopersicon esculentum \\
\hline JT510 & & 2 & $\mathrm{IVa}$ & 5 & Reunion Island & Solanum tuberosum \\
\hline JT511 & & 2 & IVa & IV 19 & Reunion Island & Solanum tuberosum \\
\hline JT512 & & 2 & $\mathrm{IVa}$ & IV 19 & Reunion Island & Lycopersicon esculentum \\
\hline JT513 & & 2 & $\mathrm{IVa}$ & IV 19 & Reunion Island & Solanum tuberosum \\
\hline JT514 & & 2 & IVa & IV 17 & Reunion Island & Solanum tuberosum \\
\hline JT515 & & 2 & $\mathrm{IVa}$ & IV 17 & Reunion Island & Lycopersicon esculentum \\
\hline JT516 & & 2 & IVa & IV 17 & Reunion Island & Solanum tuberosum \\
\hline JQ1102 & & 2 & $\mathrm{IVa}$ & & Reunion Island & Solanum tuberosum \\
\hline JQ1120 & & 2 & $\mathrm{IVa}$ & & Reunion Island & Solanum tuberosum \\
\hline JQ1084 & & 2 & $\mathrm{IVa}$ & & Reunion Island & Solanum tuberosum \\
\hline JQ1041 & & 2 & IVa & & Reunion Island & Solanum tuberosum \\
\hline JQ1051 & & 2 & IVa & & Reunion Island & Lycopersicon esculentum \\
\hline JQ1056 & & 2 & $\mathrm{IVa}$ & IV 27 & Reunion Island & Cyphomendra betacea \\
\hline JS780 & CFBP 2148 & 2 & $\mathrm{IVa}$ & IV 18 & Reunion Island & Solanum tuberosum \\
\hline JQ1144 & & 2 & IVa & & Peru & Solanum tuberosum \\
\hline JS738 & CFBP 1413 & 2 & IVa & & Australia & Solanum tuberosum \\
\hline JS737 & CFBP 1417 & 2 & IVa & & Australia & Solanum tuberosum \\
\hline JS758 & CFBP 1420 & 2 & $\mathrm{IVa}$ & IV 25 & Colombia & Solanum phureja \\
\hline JS792 & CFBP 1810 & 2 & $\mathrm{IVa}$ & IV 20 & Haiti & Solanum tuberosum \\
\hline JS774 & CFBP 1414 & 2 & IVa & & Colombia & Solanum tuberosum \\
\hline
\end{tabular}


Table 1 (cont.)

\begin{tabular}{|c|c|c|c|c|c|c|}
\hline Strain* & $\begin{array}{c}\text { Other } \\
\text { designation } \dagger\end{array}$ & $\begin{array}{l}\text { Biovar or } \\
\text { taxon }\end{array}$ & $\begin{array}{l}\text { PCR-RFLP } \\
\text { cluster and } \\
\text { subcluster }\end{array}$ & $\begin{array}{l}\text { AFLP cluster } \\
\text { and profile } \neq\end{array}$ & Geographical origin & Host \\
\hline JS887 & CFBP 3785 & 2 & $\mathrm{IVa}$ & & Portugal & Unknown \\
\hline JS895 & CFBP 3673 & 2 & $\mathrm{IVa}$ & IV 19 & France & Solanum tuberosum \\
\hline JS897 & CFBP 3103 & 2 & $\mathrm{IVa}$ & & Peru & Solanum tuberosum \\
\hline JS898 & CFBP 3672 & 2 & IVa & & France & Solanum tuberosum \\
\hline JS900 & CFBP 3671 & 2 & IVa & & France & Lycopersicon esculentum \\
\hline JS902 & CFBP 3581 & 2 & $\mathrm{IVa}$ & & France & Solanum tuberosum \\
\hline JS905 & CFBP 3582 & 2 & $\mathrm{IVa}$ & IV 19 & Egypt & Solanum tuberosum \\
\hline JS908 & CFBP 3525 & 2 & $\mathrm{IVa}$ & IV 19 & Morocco & Solanum tuberosum \\
\hline JS907 & CFBP 3858 & 2 & $\mathrm{IVa}$ & IV 19 & The Netherlands & Solanum tuberosum \\
\hline JS925 & NCBBP 1323 & 2 & $\mathrm{IVa}$ & IV 19 & Sri Lanka & Solanum tuberosum \\
\hline JS926 & NCBBP 1331 & 2 & $\mathrm{IVa}$ & IV 22 & India & Solanum tuberosum \\
\hline JS928 & NCBBP 2797 & 2 & $\mathrm{IVa}$ & IV 19 & Sweden & Solanum dulcamara \\
\hline JS929 & NCBBP 2505 & 2 & IVa & & Sweden & Solanum tuberosum \\
\hline JS930 & NCBBP 1489 & 2 & $\mathrm{IVa}$ & IV 21 & Madeira & Solanum tuberosum \\
\hline JS931 & NCBBP 1049 & 2 & $\mathrm{IVa}$ & IV 26 & Kenya & Lycopersicon esculentum \\
\hline JS932 & NCBBP 1614 & 2 & IVa & IV 23 & Malaysia & Solanum tuberosum \\
\hline JS935 & NCBBP 339 & 2 & $\mathrm{IVa}$ & & Israel & Unknown \\
\hline JS937 & NCBBP 1789 & 2 & IVa & IV 24 & Greece & Solanum tuberosum \\
\hline JS939 & NCBBP 1824 & 2 & IVa & & Egypt & Solanum tuberosum \\
\hline JS942 & NCBBP 1019 & 2 & $\mathrm{IVa}$ & IV 24 & Portugal & Lycopersicon esculentum \\
\hline JS943 & NCBBP 613 & 2 & IVa & IV 24 & Brazil & Solanum tuberosum \\
\hline JS948 & NCBBP 2088 & 2 & $\mathrm{IVa}$ & IV 24 & Nigeria & Solanum tuberosum \\
\hline JT572 & NCBBP 752 & 2 & $\mathrm{IVa}$ & IV 24 & Zimbabwe & Solanum tuberosum \\
\hline JT573 & NCBBP 8088 & 2 & IVa & IV 24 & Rwanda & Solanum tuberosum \\
\hline JT646 & UW73 & 2 & $\mathrm{IVa}$ & & Sri Lanka & Solanum tuberosum \\
\hline JT650 & UW257 & 2 & $\mathrm{IVa}$ & & Costa Rica & Solanum tuberosum \\
\hline JT653 & UW470 & $\mathrm{N} 2$ & $\mathrm{IVa}$ & & Brazil & Solanum tuberosum \\
\hline JT658 & $\mathrm{R} 361$ & $\mathrm{~N} 2$ & $\mathrm{IVa}$ & & Peru & Solanum tuberosum \\
\hline JT660 & $\mathrm{R} 578$ & $\mathrm{~N} 2$ & IVa & & Peru & Solanum melongena \\
\hline JT683 & R587 & $\mathrm{N} 2$ & $\mathrm{IVa}$ & & Peru & Solanum tuberosum \\
\hline JT662 & R330 & $\mathrm{N} 2$ & $\mathrm{IVa}$ & & Brazil & Solanum tuberosum \\
\hline JT676 & NCBBP 3990 & $\mathrm{~N} 2$ & $\mathrm{IVa}$ & & Peru & Solanum tuberosum \\
\hline JT686 & R572 & $\mathrm{N} 2$ & $\mathrm{IVa}$ & IV 29 & Brazil & Solanum american \\
\hline JT687 & R564 & $\mathrm{N} 2$ & $\mathrm{IVb}$ & & Brazil & Solanum sysynbri \\
\hline JT677 & NCBBP 3987 & $\mathrm{~N} 2$ & $\mathrm{IVb}$ & IV 31 & Brazil & Solanum tuberosum \\
\hline JT689 & $\mathrm{R} 574$ & $\mathrm{~N} 2$ & IVc & IV 30 & Peru & Lycopersicon esculentum \\
\hline JT673 & NCBBP 3985 & $\mathrm{~N} 2$ & IVc & & Peru & Solanum melongena \\
\hline JT654 & UW477 & $\mathrm{N} 2$ & $\mathrm{IVd}$ & IV 28 & Peru & Solanum tuberosum \\
\hline JS730 & CFBP 1482 & 1 & $\mathrm{~V}$ & & Panama & Musa sp. \\
\hline JS775 & CFBP 1409 & 1 & $\mathrm{~V}$ & III 14 & Honduras & Musa sp. \\
\hline JS793 & CFBP 1183 & 1 & $\mathrm{~V}$ & & Costa Rica & Heliconia sp. \\
\hline JS791 & CFBP 1416 & 1 & $\mathrm{~V}$ & & Costa Rica & Musa sp. cv. plantain \\
\hline JS748 & CFBP 1416 & 1 & $\mathrm{~V}$ & & Costa Rica & Musa sp. cv. plantain \\
\hline JT644 & UW9 & 1 & $\mathrm{~V}$ & III 15 & Costa Rica & Heliconia sp. \\
\hline JS781 & CFBP 1185 & 3 & Via & VI 43 & Japan & Lycopersicon esculentum \\
\hline JS836 & UW8 & 3 & Via & VI 44 & Costa Rica & Eupatorium odoratum \\
\hline JS842 & UW119 & 3 & Via & & Costa Rica & Solanum tuberosum \\
\hline JS940 & NCBBP 500 & 3 & Via & VI 45 & Mauritius & Vicia faba \\
\hline JS944 & NCBBP 501 & 3 & Via & & Mauritius & Brassica oleracea \\
\hline JS945 & MAFF 301860 & 3 & Via & & Japan & Capsicum annuum \\
\hline JS954 & NCBBP 502 & 3 & Via & & Mauritius & Casuarina equisetifolia \\
\hline
\end{tabular}


Table 1 (cont.)

\begin{tabular}{|c|c|c|c|c|c|c|}
\hline Strain* & $\begin{array}{c}\text { Other } \\
\text { designation } \dagger\end{array}$ & $\begin{array}{l}\text { Biovar or } \\
\text { taxon }\end{array}$ & $\begin{array}{l}\text { PCR-RFLP } \\
\text { cluster and } \\
\text { subcluster }\end{array}$ & $\begin{array}{l}\text { AFLP cluster } \\
\text { and profile } \neq\end{array}$ & Geographical origin & Host \\
\hline JS955 & NCBBP 503 & 3 & Via & & Mauritius & Dahlia sp. \\
\hline JS743 & CFBP 1418 & 3 & Via & & Costa Rica & Heliconia sp. \\
\hline JS763 & & 3 & Via & & Indonesia & Unknown \\
\hline JS941S & NCBBP 3190 & 4 & Via & VI 46 & Malaysia & Lycopersicon esculentum \\
\hline JS832 & UW378 & 4 & Via & & China & Olea sp. \\
\hline JS834 & UW151 & 4 & Via & VI 56 & Australia & Zingiber officinale \\
\hline JS835 & UW360 & 4 & Via & & China & Morus alba \\
\hline JS839 & UW369 & 4 & Via & & China & Arachis hypogaea \\
\hline JT651 & UW359 & 4 & Via & & China & Zingiber officinale \\
\hline JT517 & & 3 & VIb & VI 47 & Reunion Island & Pelargonium asperum \\
\hline JT518 & & 3 & VIb & VI 48 & Reunion Island & Solanum melongena \\
\hline JT519 & & 3 & $\mathrm{VIb}$ & & Reunion Island & Unknown \\
\hline JT520 & & 3 & $\mathrm{VIb}$ & VI 48 & Reunion Island & Pelargonium asperum \\
\hline JT521 & & 3 & VIb & VI 48 & Reunion Island & Lycopersicon esculentum \\
\hline JT522 & & 3 & VIb & VI 48 & Reunion Island & Lycopersicon esculentum \\
\hline JT523 & & 3 & VIb & VI 48 & Reunion Island & Solanum tuberosum \\
\hline JT524 & & 3 & VIb & VI 48 & Reunion Island & Lycopersicon esculentum \\
\hline JQ1060 & & 3 & $\mathrm{VIb}$ & & Reunion Island & Solanum tuberosum \\
\hline JQ1123 & & 3 & VIb & & Reunion Island & Solanum tuberosum \\
\hline JQ1090 & & 3 & VIb & & Reunion Island & Solanum tuberosum \\
\hline JQ1114 & & 3 & VIb & & Reunion Island & Solanum tuberosum \\
\hline JQ1072 & & 3 & VIb & VI 48 & Reunion Island & Allium cepa \\
\hline JQ1104 & & 3 & $\mathrm{VIb}$ & & Reunion Island & Solanum tuberosum \\
\hline JQ1138 & & 3 & VIb & & Reunion Island & Solanum tuberosum \\
\hline JQ1024 & & 3 & VIb & & Reunion Island & Lycopersicon esculentum \\
\hline JQ1129 & & 3 & VIb & & Reunion Island & Lycopersicon esculentum \\
\hline JQ1134 & & 3 & VIb & VI 49 & Reunion Island & Anthurium andreanum \\
\hline JS766 & CFBP 726 & 3 & VIb & VI 48 & Reunion Island & Solanum melongena \\
\hline JS778 & CFBP 2041 & 3 & VIb & VI 48 & Reunion Island & Solanum tuberosum \\
\hline JS747 & CFBP 726 & 3 & VIb & & Reunion Island & Solanum melongena \\
\hline JT571 & ICMP 759 & 3 & VIb & & Kenya & Solanum melongena \\
\hline JT674 & NCBBP 1045 & 3 & VIb & VI 48 & Kenya & Solanum melongena \\
\hline JT678 & NCBBP 1486 & 3 & VIb & VI 48 & Uganda & Arachis hypogaea \\
\hline JT675 & NCBBP 1763 & 3 & VIb & VI 48 & Seychelles & Lycopersicon esculentum \\
\hline JT574 & NCBBP 7960 & 4 & VIb & & Kenya & Capsicum annuum \\
\hline JS841 & UW74 & 4 & $\mathrm{VIb}$ & VII 58 & Sri Lanka & Solanum tuberosum \\
\hline JS933 & MAFF 301418 & 4 & VIb & & Japan & Lycopersicon esculentum \\
\hline JT690 & MAFF 211266 & 1 & VIb & 40 & Japan & Lycopersicon esculentum \\
\hline JT691 & MAFF 211267 & 1 & VIb & 40 & Japan & Lycopersicon esculentum \\
\hline JS722 & CFBP 1813 & 3 & VIc & & Guyana & Solanum melongena \\
\hline JS718 & CFBP 2480 & 3 & VIc & & Guadeloupe & Solanum melongena \\
\hline JS729 & CFBP 2965 & 3 & VIc & VI 50 & Guadeloupe & Solanum melongena \\
\hline JS719 & CFBP 2970 & 3 & VIc & & Martinique & Capsicum annuum \\
\hline JS715 & CFBP 2976 & 3 & VIc & & Martinique & Ensete ventricosum \\
\hline JS753 & GMI1000 & 3 & VIc & VI 52 & Guyana & Lycopersicon esculentum \\
\hline JS759 & CFBP 1168 & 3 & VIc & VI 50 & Trinidad and Tobago & Musa sp. \\
\hline JS772 & CFBP 707 & 3 & VIc & VI 53 & Tahiti & Lycopersicon esculentum \\
\hline JS773 & CFBP 1960 & 3 & VIc & VI 50 & Algeria & Capsicum annuum \\
\hline JS840 & UW147 & 3 & VIc & VI 54 & Australia & Nicotiana tabacum \\
\hline JS843 & UW130 & 3 & VIc & VI 51 & Peru & Lycopersicon esculentum \\
\hline JT647 & UW152 & 3 & VIc & & Australia & Solanum tuberosum \\
\hline
\end{tabular}


Table 1 (cont.)

\begin{tabular}{|c|c|c|c|c|c|c|}
\hline Strain* & $\begin{array}{c}\text { Other } \\
\text { designation } \dagger\end{array}$ & $\begin{array}{l}\text { Biovar or } \\
\text { taxon }\end{array}$ & $\begin{array}{l}\text { PCR-RFLP } \\
\text { cluster and } \\
\text { subcluster }\end{array}$ & $\begin{array}{l}\text { AFLP cluster } \\
\text { and profile } \neq\end{array}$ & Geographical origin & Host \\
\hline JS782 & CFBP 1038 & 3 & VIc & & Guadeloupe & Lycopersicon esculentum \\
\hline JS888 & CFBP 3258 & 3 & VIc & & Unknown & Unknown \\
\hline JS947 & NCBBP 1123 & 4 & VIc & VII 59 & Papua New Guinea & Lycopersicon esculentum \\
\hline JS953 & MAFF 301552 & 3 & VId & VI 55 & Japan & Lycopersicon esculentum \\
\hline JS936 & NCBBP 3181 & 3 & VIe & 57 & Gambia & Solanum nicanum \\
\hline JS904 & CFBP 3059 & 1 & VIe & 32 & Burkina Faso & Solanum melongena \\
\hline JT661 & R292 & 5 & VIf & VII 60 & China & Morus alba \\
\hline JT685 & R322 & 5 & VIf & VII 61 & China & Morus alba \\
\hline JS950 & NCBBP 1018 & 1 & VIIa & V 33 & Angola & Solanum tuberosum \\
\hline JT525 & & 1 & VIIb & V 34 & Reunion Island & Pelargonium asperum \\
\hline JT526 & & 1 & VIIb & V 34 & Reunion Island & Pelargonium asperum \\
\hline JT527 & & 1 & VIIb & V 34 & Reunion Island & Pelargonium asperum \\
\hline JT528 & & 1 & VIIb & V 34 & Reunion Island & Solanum tuberosum \\
\hline JT529 & & 1 & VIIb & V 34 & Reunion Island & Pelargonium asperum \\
\hline JT530 & & 1 & VIIb & V 34 & Reunion Island & Pelargonium asperum \\
\hline JT531 & & 1 & VIIb & V 34 & Reunion Island & Solanum tuberosum \\
\hline JQ1040 & & 1 & VIIb & V 34 & Reunion Island & Lycopersicon esculentum \\
\hline JT532 & & 1 & VIIb & & Reunion Island & Unknown \\
\hline JS756 & CFBP 2146 & 1 & VIIb & V 35 & Reunion Island & Pelargonium capitatum \\
\hline JS767 & CFBP 734 & 1 & VIIb & V 36 & Madagascar & Solanum tuberosum \\
\hline JS946 & NCBBP 283 & 1 & VIIb & V 37 & Zimbabwe & Solanum panduraforme \\
\hline JS949 & NCBBP 332 & 1 & VIIb & V 38 & Zimbabwe & Solanum tuberosum \\
\hline JS951 & NCBBP 505 & 1 & VIIb & V 39 & Zimbabwe & Symphytum sp. \\
\hline JS952 & NCBBP 342 & 1 & VIIb & & Zimbabwe & Nicotiana tabacum \\
\hline JS966 & ICMP 748 & 1 & VIIb & & Zimbabwe & Solanum tuberosum \\
\hline JS934\$ & MAFF 301558 & $\mathrm{~N} 2$ & VIIc & 62 & Japan & Solanum tuberosum \\
\hline JT656 & $\mathrm{R} 604$ & $\mathrm{BDB}$ & $\mathrm{IXb}$ & 42 & Indonesia & Musa sp. \\
\hline JT657 & $\mathrm{R} 230$ & $\mathrm{BDB}$ & $\mathrm{IXb}$ & & Indonesia & Musa sp. \\
\hline \multirow[t]{2}{*}{ JT680 } & NCBBP 3726 & $\mathrm{BDB}$ & $\mathrm{IXb}$ & & Indonesia & Musa sp. \\
\hline & R006 & P. syzygii & IXc & & Indonesia & Syzygium aromaticum \\
\hline JV1010 & $\mathrm{R} 024$ & P. syzygii & $\mathrm{IXa}$ & & Indonesia & Syzygium aromaticum \\
\hline JV1011 & $\mathrm{R} 028$ & P. syzygii & $\mathrm{IXa}$ & & Indonesia & Syzygium aromaticum \\
\hline JR660 & CFBP 2459 & R. pickettii & & 41 & Unknown & Unknown \\
\hline
\end{tabular}

* Designation of strains of the Laboratoire de Phytopathologie, CIRAD-FLHOR, 97448 Saint-Pierre, La Réunion, France.

† CFBP , Collection Française de Bactéries Phytopathogènes, Angers, France; NCPPB , National Collection of Plant Pathogenic Bacteria, Harpenden, UK; ICMP , International Collection of Microorganisms from Plants, Auckland, New Zealand; UW, D. Cook and L. Sequeira, Department of Plant Pathology, University of Wisconsin-Madison, USA; GMI, M. Arlat and P. Barberis, CNRS-INRA, Auzeville, Castanet-Tolosan Cedex, France; MAFF, Ministry of Agriculture Forestry and Fisheries, National Institute of Agrobiological Resources, Japan; R, Institute of Arable Crops Research-Rothamsted, Harpenden, UK.

$\ddagger$ Roman numerals indicate AFLP clusters and arabic numerals indicate AFLP profiles.

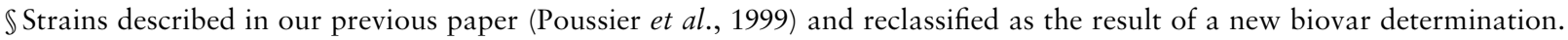

in this paper. Firstly, 59 additional strains of $R$. solanacearum, including biovar $\mathrm{N} 2$ and 5 strains and new African strains, were analysed using PCR-RFLP. Two close relatives of $R$. solanacearum, Pseudomonas syzygii (causal agent of Sumatra disease of cloves) and the blood disease bacterium (BDB, causal agent of blood disease of bananas) (Eden-Green, 1994; Seal et al., 1993; Taghavi et al., 1996) were also analysed, permitting the specificity of our PCR-RFLP test and the phylogenetic relationships between these three bacteria to be assessed. Secondly, we have used the very powerful DNA fingerprinting technique AFLP (Vos et al., 1995), which allows very fine whole genome analysis. AFLP methodology has already been used to study the diversity of race 3 isolates of $R$. solanacearum (Van der Wolf et al., 1998) but has never been used to analyse a worldwide collection of $R$. solanacearum strains. Finally, we have determined nearly complete $16 \mathrm{~S}$ rRNA gene sequences for seven (five African, one American and one Japanese) biovar 1 strains of $R$. solanacearum, and compared these 
with 19 previously sequenced $R$. solanacearum $16 \mathrm{~S}$ rRNA gene sequences (Taghavi et al., 1996).

\section{METHODS}

Bacterial strains and culture conditions. Bacterial strains used in this study are listed in Table 1 . Culture conditions and biovar determination of $R$. solanacearum isolates were as described previously (Poussier et al., 1999).

DNA isolation. Genomic DNA of strains was extracted using the hexadecyltrimethylammonium bromide method (Ausubel et al., 1991).

PCR-RFLP analysis. DNA amplification conditions and digestion with eight restriction endonucleases of the five PCR products were as previously described (Poussier et al., 1999). Each PCR-RFLP was duplicated to assure its reproducibility. Two different Hierarchical Cluster Analysis (HCA) methods were used to analyse the PCR-RFLP band data collected. Using STATLAB version 2.0 (SLP Statistiques, Monterey, CA, USA), clustering was based on the Euclidean distance between strains (Ward, 1963). The truncation level in the resulting dendrogram was thus determined to be that which provided the smallest number of clusters for which the variance within clusters was significantly $(P=0 \cdot 05)$ different from the variance between clusters. Using the PHYLIP software package (Felsenstein, 1995), a distance matrix was firstly constructed with the Nei (1973) genetic distance of the GENDIST program. A dendrogram was then constructed from genetic distance values by using the unweighted pair group method with arithmetic averages (UPGMA) (Sneath \& Sokal, 1973) contained in the NEIGHBOR program. Finally, the strength of the tree topology was assessed by the bootstrap method (Felsenstein, 1985) of the SEQBOOT program.

AFLP analysis. Ninety-six R. solanacearum strains, one BDB strain and one Ralstonia pickettii strain were analysed using AFLP as described by Janssen et al. (1996) and Vos et al. (1995) with slight modifications. We used MspI and SacI to digest DNA instead of EcoRI and MseI.

Genomic DNA (200 ng per sample) was digested for $2 \mathrm{~h}$ at $37^{\circ} \mathrm{C}$ in $50 \mu \mathrm{l}$ (final volume) containing $5 \mathrm{U}$ MspI, $5 \mathrm{U}$ SacI (Amersham Pharmacia Biotech), $0 \cdot 125 \mu \mathrm{l}$ BSA $\left(10 \mu \mathrm{g}^{-1}\right)$ and $2.5 \mu \mathrm{l} 10 \times$ 'One Phor All' buffer (Amersham). Next, $50 \mathrm{pmol}$ double-stranded MspI-adapter (5'-GACGATGAGTCCTGAA-3', 5'-CGTTCAGGACTCATC-3') (50 pmol $\left.\mu \mathrm{l}^{-1}\right)$, $5 \mathrm{pmol}$ double-stranded SacI-adapter (5'-CTCGTAGACTGCGTACAAGCT-3'， 5'-TGTACGCAGTCTAC-3') $\left(5 \mathrm{pmol}^{\prime} \mathrm{l}^{-1}\right)$ (Genset), $1 \mu \mathrm{l}$ ATP $(10 \mathrm{mM}), 1 \mathrm{U}$ T4 DNA ligase $\left(5 \mathrm{U}^{-1}\right)$ (Appligene) and $2 \cdot 5 \mu \mathrm{l} 10 \times$ 'One Phor All' buffer were added to the digested DNA and the ligation reactions were performed for $3 \mathrm{~h}$ at $20^{\circ} \mathrm{C}$. Digested (D) and ligated (L) DNA were diluted (D) eightfold and the resulting DLD DNA was then stored at $4{ }^{\circ} \mathrm{C}$ until used.

Selective amplifications were done with two primers (MspIprimer and SacI-primer) (Genset) complementary to the adapter sequences, and the MspI and SacI restriction sites respectively, with additional selective nucleotides at their 3' ends (cytosine for the SacI-primer and cytosine plus guanine for the MspI-primer). The SacI-primer was labelled with $\gamma-{ }^{33} \mathrm{P}$ $[10 \mu \mathrm{Ci}(370 \mathrm{kBq})$ per DNA amplification; Nen Life Science Products] and T4 polynucleotide kinase (Gibco-BRL).

DNA amplifications were carried out in a $50 \mu$ l reaction mixture. DLD DNA $(5 \mu \mathrm{l})$ was added to $45 \mu \mathrm{l}$ mixture containing $5 \mu \mathrm{l} 10 \times$ PCR buffer (Gibco-BRL), $1.5 \mu$ labelled SacI-primer $\left(50 \mu \mathrm{g}^{-1}\right), 2 \mu \mathrm{l}$ unlabelled MspI-primer $(30 \mu \mathrm{g}$ $\left.\mu \mathrm{l}^{-1}\right), 1.5 \mu \mathrm{lgCl}_{2}(50 \mathrm{mM}), 8 \mu \mathrm{l}$ of each dNTP $(1.25 \mathrm{mM})$ and
$0.6 \mu \mathrm{l} \mathrm{Taq}$ polymerase $\left(5 \mathrm{U}_{\mu} \mathrm{l}^{-1}\right.$; Gibco-BRL). Amplifications were performed with a thermocycler (Mastercycler gradient Eppendorf) by using the following protocol: 30 cycles consisting of denaturation at $94^{\circ} \mathrm{C}$ for $30 \mathrm{~s}$, annealing at $56^{\circ} \mathrm{C}$ for $1 \mathrm{~min}$ and extension at $72{ }^{\circ} \mathrm{C}$ for $1 \mathrm{~min}$.

Amplified fragments were separated by electrophoresis on $5 \%$ polyacrylamide gels and fingerprint patterns were visualized as described by Vos et al. (1995). The reproducibility of AFLP was assessed by comparing the DNA fingerprinting obtained from duplicate assays of 14 strains. Duplicate DNA fingerprints were produced using two aliquots from two different DNA amplifications that were run in different gels. AFLP data analysis was performed as described above for PCR-RFLP.

$16 \mathrm{~S}$ rRNA sequencing. Seven biovar 1 strains of $R$. solanacearum were used: CFBP 1036, CFBP 712, NCPPB 1018, CFBP 2146, CFBP 734, NCPPB 342 and MAFF 211266. 16S rRNA genes were amplified using the PCR as detailed by Taghavi et al. (1996) with slight modifications. PCR amplifications were carried out in a thermocycler (GeneAmp PCR system 9600; Perkin-Elmer) in a $50 \mu \mathrm{l}$ (total volume) reaction mixture containing $10 \times$ buffer $(200 \mathrm{mM}$ Tris $/ \mathrm{HCl}, 500 \mathrm{mM}$ $\mathrm{KCl}$, pH 8.4; Gibco-BRL), $1.5 \mathrm{mM} \mathrm{MgCl}_{2}$ (Gibco-BRL) $200 \mu \mathrm{M}$ of each dNTP (Boehringer Mannheim), 0.25 $\mu \mathrm{M}$ primer $27 \mathrm{f}, 0 \cdot 25 \mu \mathrm{M}$ primer $1525 \mathrm{r}$ (Genosys Biotechnologies) (Taghavi et al., 1996), $1 \mathrm{U}$ Taq polymerase (Gibco-BRL) and 100 ng template DNA. The following PCR profile was used: initial denaturation at $96{ }^{\circ} \mathrm{C}$ for $2 \mathrm{~min} ; 30$ cycles consisting of $94^{\circ} \mathrm{C}$ for $30 \mathrm{~s}, 60^{\circ} \mathrm{C}$ for $1 \mathrm{~min}$ and $72^{\circ} \mathrm{C}$ for $1 \mathrm{~min}$; and final extension at $72{ }^{\circ} \mathrm{C}$ for $10 \mathrm{~min}$.

PCR products were electrophoresed using $1 \%$ agarose gels at $5 \mathrm{~V} \mathrm{~cm}^{-1}$ for $1 \mathrm{~h}$ and visualized with UV light after ethidium bromide staining. Amplification products were purified from the agarose gel slice by using the QIAquick purification kit PCR (Qiagen) according to the manufacturer's instructions.

PCR product sequences were determined by Cambridge Bioscience, Cambridge, UK. The GenBank accession numbers of the seven resulting $16 \mathrm{~S}$ rRNA gene sequences are shown in Table 3. They were aligned using the 'gap proceed' program of the Genetics Computer Group software package (Genetics Computer Group, 1999) with the published 16S rRNA gene sequences of $R$. solanacearum, BDB and $P$. syzygii isolates studied by Taghavi et al. (1996). Data analysis was performed using the DNADIST (Jukes \& Cantor, 1969) and NEIGHBOR (UPGMA method) programs of the PHYLIP software package, and using the STATLAB software.

\section{RESULTS \\ PCR-RFLP analysis}

Both of the bacteria closely related to $R$. solanacearum that were examined, P. syzygii and the BDB, which were not included in our previous study (Poussier et al., 1999), gave a single band of the expected size after amplification using each of the five pairs of primers. After suitable digestion of the amplicons, the $\mathrm{BDB}$ and $P$. syzygii strains could be separated from the $R$. solanacearum strains. Indeed, their resulting profiles displayed specific restriction patterns (Table 2). Pattern DHa7 (band sizes 608 and $281 \mathrm{bp}$ ) was common to the BDB and P. syzygii strains whereas APv5 (band size $1452 \mathrm{bp}$; no PvuII restriction site within the amplified fragment) was specific to P. syzygii strains. EBs7 (band sizes visible on gel $1106,125,109 \mathrm{bp}$ ) was produced by only one P. syzygii strain, R006. In addition, two restriction 
Table 2. Characterization of the eight new PCR-RFLP profiles identified within the 59 additional strains of $R$. solanacearum, three BDB strains and three $P$. syzygii strains

\begin{tabular}{|lll|}
\hline PCR-RFLP profile* & Subcluster & Organism \\
\hline AAv2, APv1, BHi2, CSa1, DHa2, EBs5, ENo2, EPs3 & IIb & R. solanacearum \\
AAv2, APv2, BHi2, CSa2, DHa2, EBs5, ENo2, EPs2 & IVb & R. solanacearum \\
AAv2, APv2, BHi2, CSa2, DHa2, EBs5, ENo3, EPs2 & IVc & R. solanacearum \\
AAv2, APv2, BHi2, CSa2, DHa2, EBs2, ENo3, EPs3 & IVd & R. solanacearum \\
AAv2, APv1, BHi7, CSa1, DHa3, EBs3, ENo1, EPs1 & VIf & R. solanacearum \\
AAv2, APv5, BHi5, CSa3, DHa7, EBs3, ENo1, EPs1 & IXa & P. syzygii \\
AAv2, APv2, BHi5, CSa3, DHa7, EBs3, ENo1, EPs1 & IXb & BDB \\
AAv2, APv5, BHi5, CSa3, DHa7, EBs7, ENo1, EPs1 & IXc & P. syzygii \\
\hline
\end{tabular}

*A profile is the combination of eight restriction patterns generated through the digestion of the five amplified fragments by the designated enzymes. Each pattern was given a code containing three letters and one number; the first letter refers to the amplified fragment (A as delineated by primers RS20RS201, B by RS30-RS31, C by RS50-RS501, D by RS600-R61 and E by RS80-RS81); the following letters

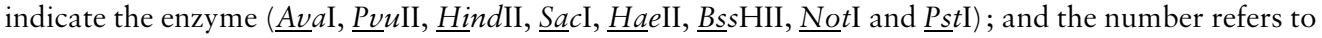
the pattern generated by the enzyme.

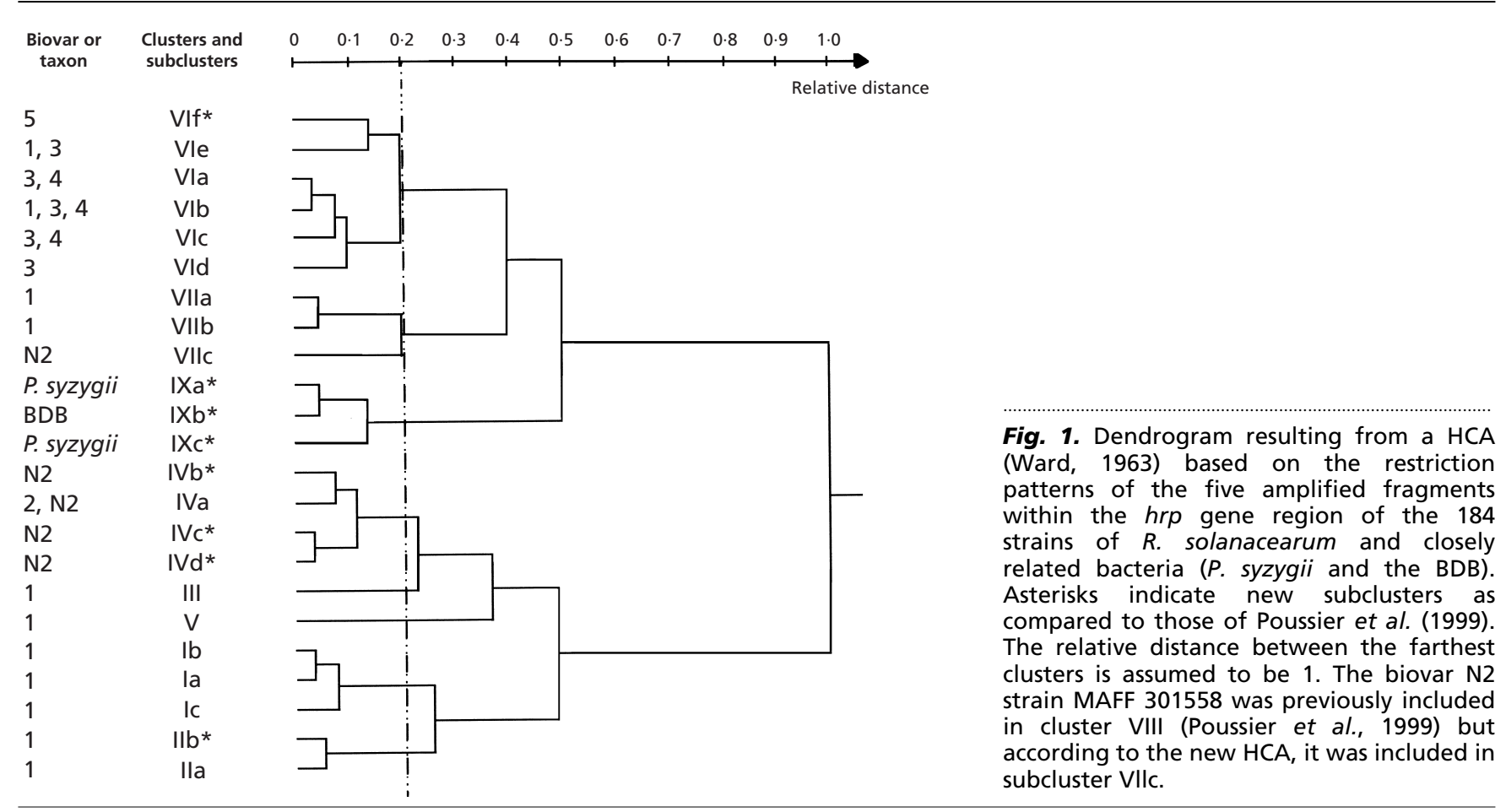

patterns, BHi5 and CSa3, produced by the BDB and $P$. syzygii strains were shared with the unique $R$. solanacearum strain MAFF 301558.

The dendrogram resulting from a HCA (Fig. 1), produced by STATLAB or PHYLIP software packages, showed that $R$. solanacearum could be separated into two divisions. The first division comprised about $64 \%$ of biovar 1 strains and all of the biovar 2 and N2 strains; the second division contained about $36 \%$ of biovar 1 strains, all of the biovar 3, 4 and 5 strains and one biovar N2 strain MAFF 301558. The BDB and P. syzygii isolates fell into the second division. No significant difference was observed between clusterings resulting from either of the two different software packages (results not shown). The dendrogram generated by the STATLAB software (Fig. 1) agreed with previous results (Poussier et al., 1999). However, amongst the additional strains, five new profiles and one new restriction pattern were identified (Table 2). In particular, the biovar 1 strain UW469 gave a new profile (IIb), whilst the Japanese and Burkina Faso biovar 1 strains (MAFF 211266, MAFF 211267 and CFBP 3059) were grouped with biovar 3 strains into subclusters VIb and VIe. Three of the identified biovar 1/race 2 isolates, UW9, UW162 and UW181, were distributed into three different clusters: subcluster IIa, cluster III and cluster V. Five of the twelve biovar N2 strains used generated three new profiles 


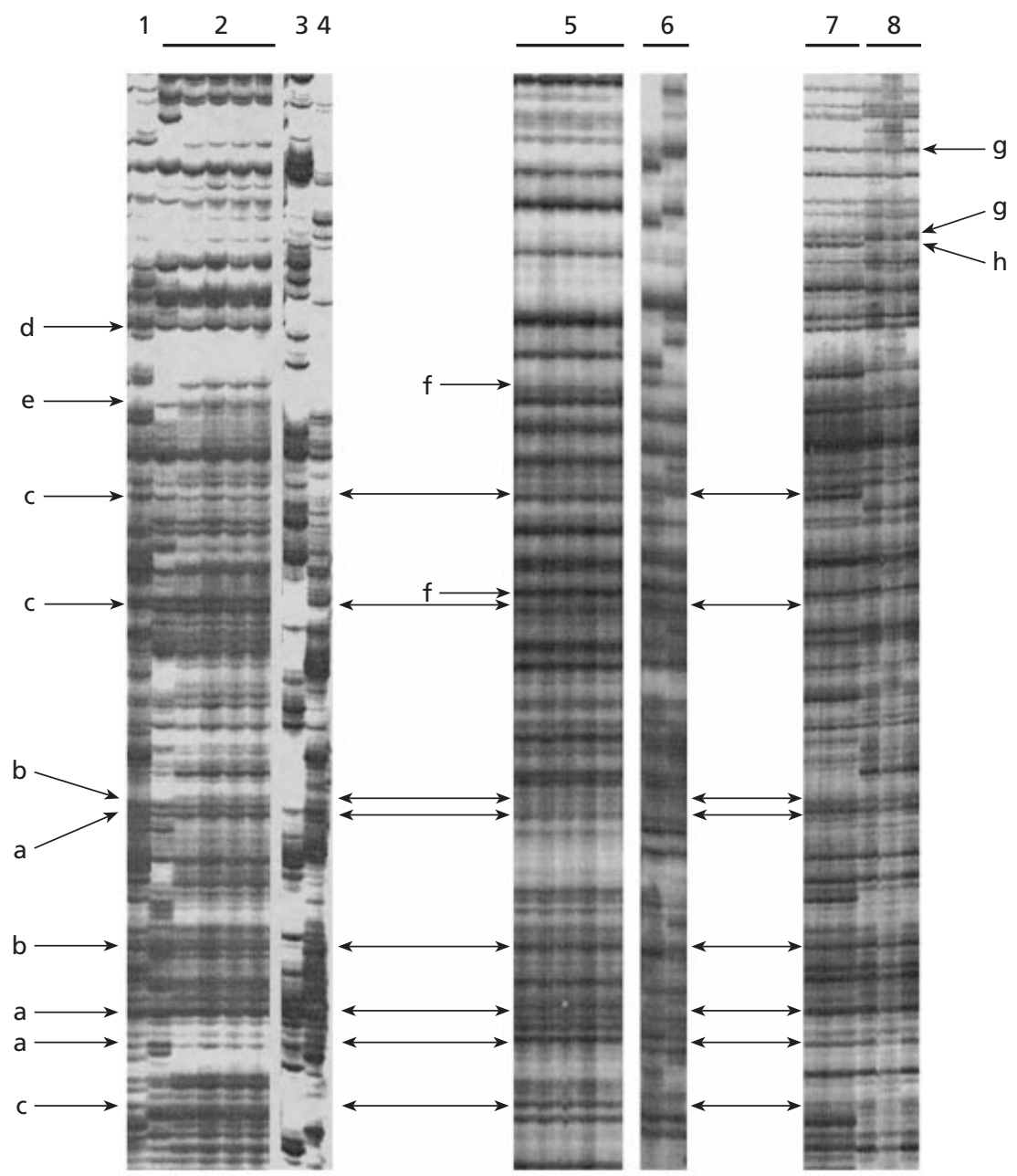

Fig. 2. A selection of AFLP fingerprints of $R$. solanacearum strains and related bacteria. Lanes: 1, Japanese biovar 1, MAFF 211267; 2, African biovar 1, NCPPB 1018, JT525, JT526, JT527，JT528; 3, R. pickettii, JR660; 4, BDB， JT657; 5, biovar 2, CFBP 3673, CFBP 3582, CFBP 3525 , CFBP 3858, NCPPB 1323; 6, biovar N2, R572, R574; 7, African biovar 3, NCPPB 1045, NCPPB 1486, NCPPB 1763; 8, non-African biovar 3, CFBP 2965, GMI1000, CFBP 1168. Arrows indicate examples of polymorphic and specific fragments. Fragments are specific to (a) $R$. solanacearum, $R$. pickettii and the $\mathrm{BDB}$; (b) R. solanacearum and the BDB; (c) $R$. solanacearum; (d) African and Japanese biovar 1; (e) African biovar 1; (f) biovar 2 and N2; (g) biovar 3, 4 and 5; (h) African biovar 3. Since five images derived from three different gels were associated to make this figure, exact alignment was not always possible (symbolized by double-headed arrows).

(IVb, IVc and IVd) and thus could be distinguished from biovar 2 strains whereas the seven remaining biovar N2 strains could not be separated (subcluster IVa). All of the new African biovar 3 strains fell into a single subcluster (VIb). Two strains belonging to biovar 5 were characterized by a new profile, VIf, and a new restriction pattern, BHi7 (band sizes 779, 745, 304 and 172 bp).

\section{AFLP analysis}

One hundred and fifty-nine DNA fragments which were reproducibly detected, ranging from 50 to $350 \mathrm{bp}$, were selected for the analysis of $96 R$. solanacearum strains and two isolates belonging to two closely related taxa: the BDB and R. pickettii. Amongst these, 62 different DNA fingerprints were identified. Different DNA fingerprints were generated from strains belonging to the same biovar (for example 23, 12 and 13 from biovars 1, 2 and 3 , respectively), but also originating from the same geographical area (for instance 6 from biovar 2 strains from Reunion Island). Identical DNA patterns could be produced by strains originating from different countries (for example IV 19 was found in strains from 7 countries).

Depending on the strain, DNA patterns contained 50-80 different DNA bands (Fig. 2). Comparison of AFLP fingerprints revealed that $95 \%$ of the fragments were polymorphic. Three fragments appeared to be specific to $R$. solanacearum species. Moreover, five AFLP fragments were common to all $R$. solanacearum strains: three of them were shared with the BDB and R. pickettii strains and two of them were shared with only the BDB strains. One fragment was specific to the BDB isolate. Many of the DNA fragments were useful in distinguishing subgroups within $R$. solanacearum species. For instance, one fragment was found only in all of the biovar 1, 2 and N2 strains (except for the biovar N2 strain MAFF 301558). Eight fragments were produced by all of the biovar 3, 4 and 5 strains (with one, two or three exceptions depending on the fragment). No DNA band appeared to be specific to all biovar 1 strains; however one fragment was common to all $R$. solanacearum strains other than biovar 1 strains. African and Japanese biovar 1 isolates were characterized by three and two fragments, respectively. Six particular DNA bands were specific to biovar 2 and N2 isolates, except for strains JT510 and MAFF 301558. Strain JT510 (biovar 2) was unusual since it shared less than $60 \%$ of the AFLP fragments with other biovar 2 isolates. One fragment was common to all biovar N2 strains, except 


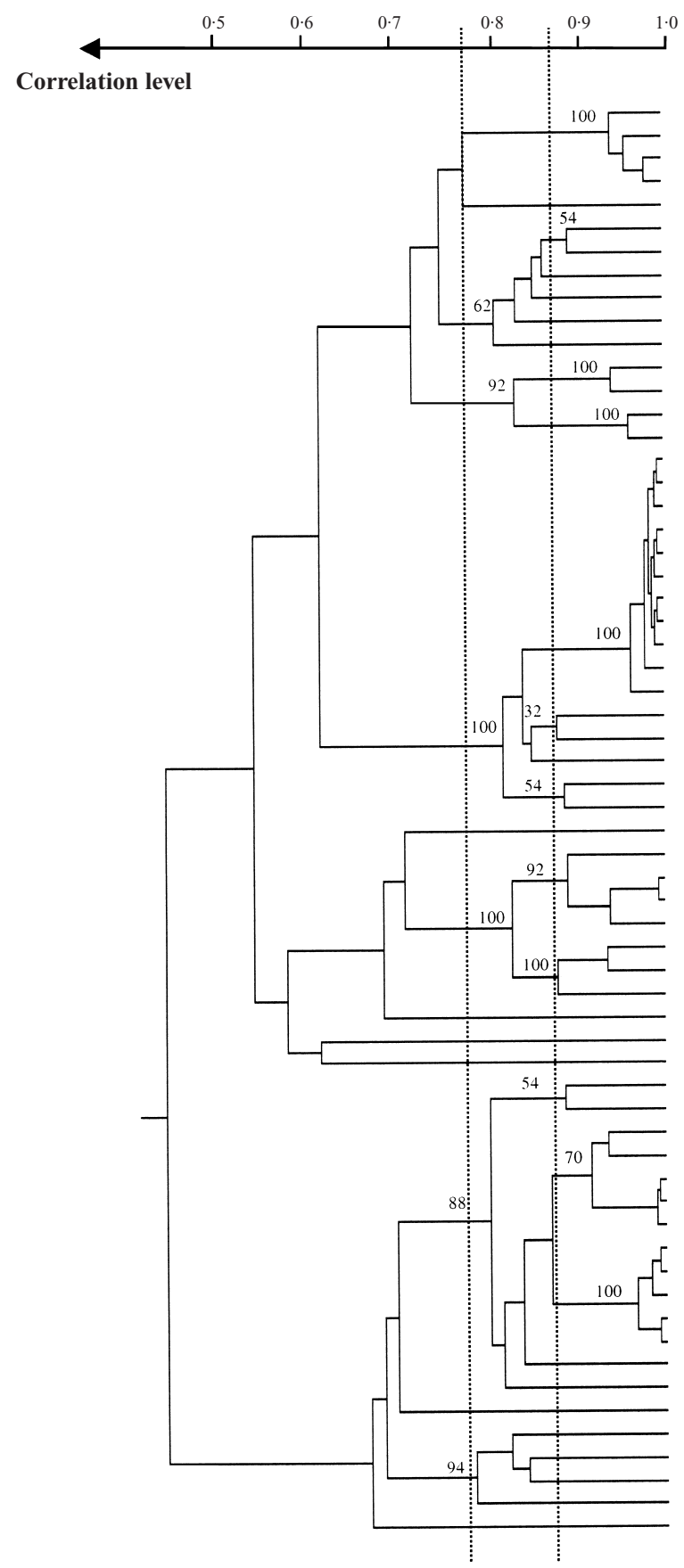

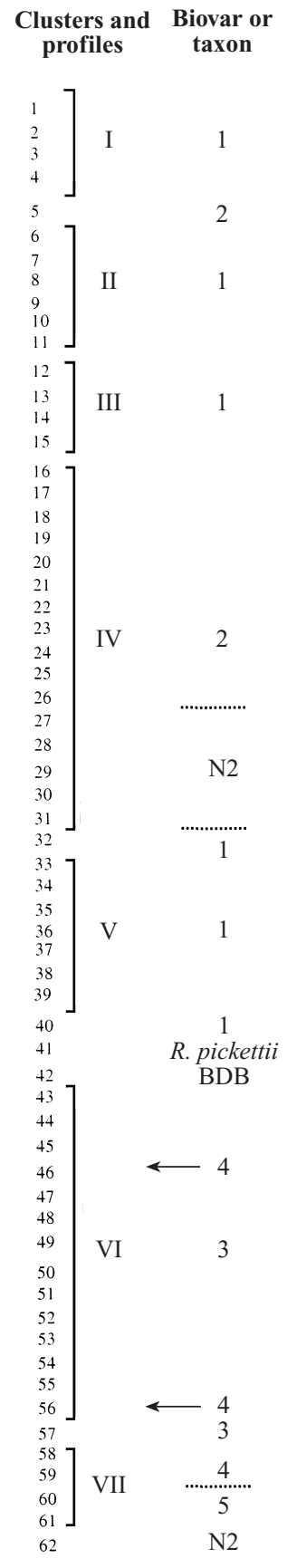

Fig. 3. Dendrogram constructed by using UPGMA showing correlation between AFLP fingerprints of $98 R$. solanacearum strains and related bacteria (the BDB and $R$. pickettii). Roman numerals indicate clusters and arabic numerals indicate profile types. Numbers at the branch points are the percentages of bootstrap replicates in which the clusters were found. for strains JT510, JQ1056 and MAFF 301558. Seventeen AFLP fragments could discriminate between the two similar biovars 2 and N2. One fragment was specific for biovar 3 strains (two exceptions) and one only for African biovar 3 strains. No fragments discriminating biovar 4 or 5 isolates were obtained, but these isolates were distinguished from biovar 3 strains by 14 DNA bands.

The dendrogram generated by the PHYLIP software package (Fig. 3) showed that $R$. solanacearum could be split into two divisions: the first division contained biovar 1, 2 and $\mathrm{N} 2$ isolates and the second division contained biovar 3, 4 and 5 isolates (except for one particular biovar N2 strain, MAFF 301558). The truncation level, at 0.78 correlation, allowed separation of seven AFLP clusters designated clusters I-VII. High bootstrap values indicated that this clustering was well supported and the tree was robust. The close relatives of $R$. solanacearum, $R$. pickettii and the BDB, were found to be in the first division and exhibited specific AFLP profiles. Clusters appeared to be grouped according to biovar, geographical origin or host origin. Clusters I, II and III included biovar 1 strains originating from the Americas (three coming from Northern Africa) whilst cluster $\mathrm{V}$ contained biovar 1 strains originating from the 


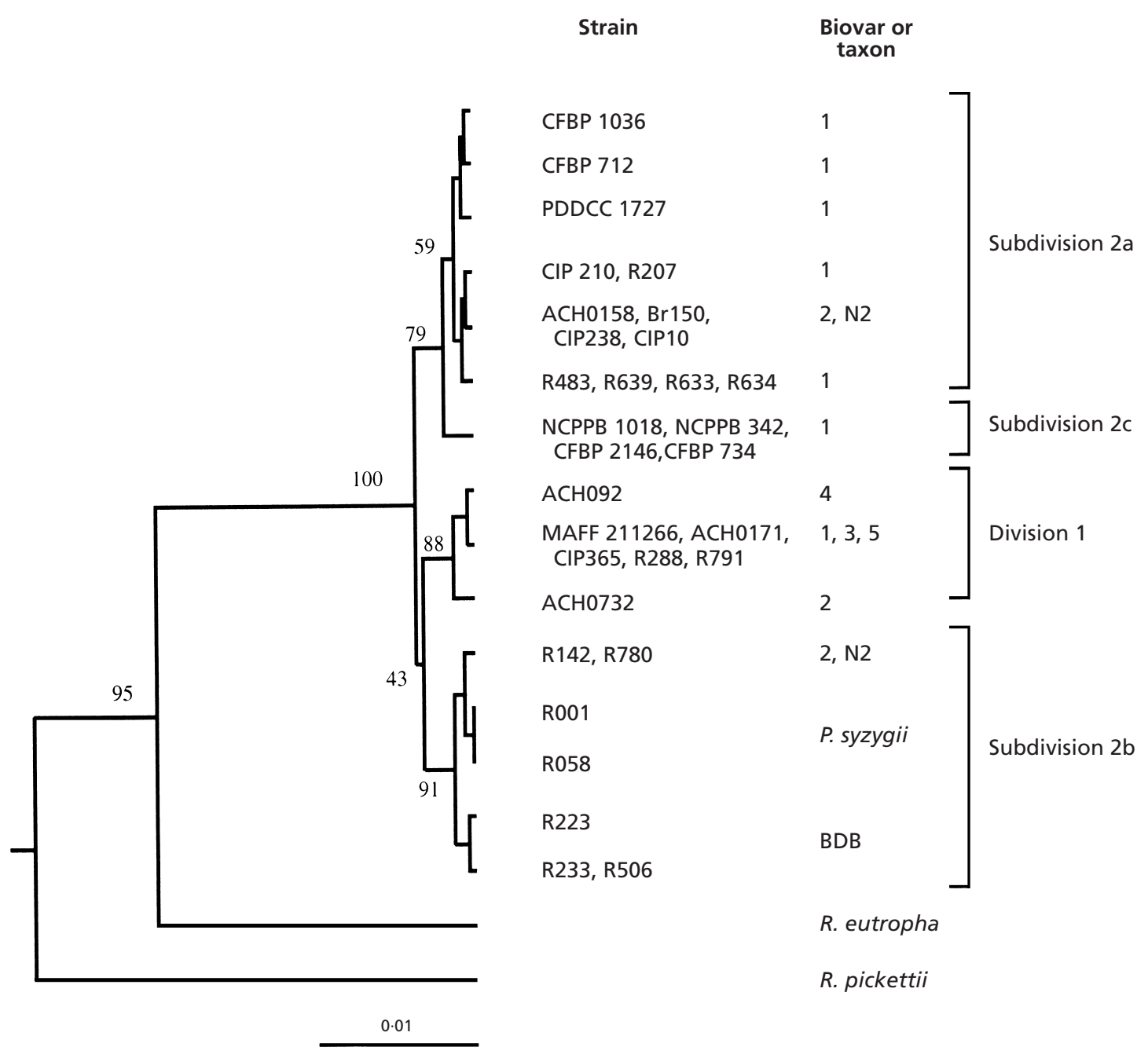

Fig. 4. Dendrogram constructed by using UPGMA showing the phylogenetic relationships of $R$. solanacearum strains and strains of closely related bacteria ( $P$. syzygii and the BDB), based on $16 \mathrm{~S}$ rDNA sequence comparisons. Ralstonia eutropha and $R$. pickettii were used as outgroups in this analysis. The numbers at the branch points are the percentages of bootstrap replicates in which the clusters were found. The GenBank accession numbers for the I6S rDNA sequences of the $R$. eutropha and $R$. pickettii strains are AF027407 and X67042, respectively.

Southern part of Africa. Strains belonging to cluster III were isolated from musaceous plants, except for one from potato. Cluster IV grouped biovar 2 and N2 isolates. Biovar 3 strains were assigned to cluster VI. Isolates belonging to biovars 4 and 5 were grouped together in cluster VII, except for two biovar 4 strains in cluster VI. Strains JT510, CFBP 3059, MAFF 211266, MAFF 211267, NCPPB 3181 and MAFF 301558 were unusual since they were members of unique branches. Moreover, a second truncation level (Fig. 3), at 0.87 correlation, could be used to make a more precise discrimination of strains, particularly between biovar 2 strains and biovar N2 strains, and between biovar 3 strains originating from Africa and biovar 3 strains from the other continents. This clustering was also well supported by high bootstrap values, except for some weaker values, $54 \%$ and $32 \%$. The clustering obtained with the STATLAB software was approximately the same as that obtained with the PHYLIP software package except that certain strains which were not well separated from the other strains using STATLAB were separated using PHYLIP (result not shown).

\section{S rRNA sequence analysis}

Nearly complete sequences of $16 \mathrm{~S}$ rRNA genes were determined for 7 biovar 1 isolates of $R$. solanacearum and compared to 24 published sequences of $R$. solanacearum isolates and the closely related bacteria, $P$. syzygii and the $\mathrm{BDB}$.

A phylogenetic tree was produced using the PHYLIP software package by comparing 1431 nucleotide positions, omitting all of the ambiguous nucleotides, and revealed two divisions, each of which was split into two subdivisions (Fig. 4). This tree was not completely consistent with that obtained by Taghavi et al. (1996) since the subdivision $2 \mathrm{~b}$ appeared to be more closely related to division 1 than to subdivision 2 a. However, 
Table 3. The $16 \mathrm{~S}$ rRNA sequence differentiation among 31 isolates of $R$. solanacearum and related bacteria

\begin{tabular}{|c|c|c|c|c|c|c|c|c|c|c|c|c|c|c|c|c|c|c|c|c|c|c|c|c|c|c|c|}
\hline \multirow[t]{2}{*}{ Organism } & \multirow[t]{2}{*}{ Strain $*$} & \multirow[t]{2}{*}{ Country } & \multirow[t]{2}{*}{ Host } & \multirow[t]{2}{*}{ Biovar } & \multirow{2}{*}{$\begin{array}{l}\text { Division or } \\
\text { subdivision }\end{array}$} & \multirow{2}{*}{$\begin{array}{c}\text { GenBank } \\
\text { accession } \\
\text { no. }\end{array}$} & \multicolumn{21}{|c|}{ Nucleotide(s) at position $(\mathrm{s}) \dagger$} \\
\hline & & & & & & & 165 & 167 & 204 & 205 & 264 & 269 & 328 & $458-460$ & 474 & 649 & 669 & 737 & 848 & 1208 & 1402 & 1424 & 1428 & 1441 & 14511 & 1456 & 1472 \\
\hline \multirow[t]{26}{*}{ R. solanacearum } & CFBP 1036 & Martinique & Tomato & 1 & $2 \mathrm{a}$ & AF207891 & $\mathrm{C}$ & A & G & A & A & $\mathrm{U}$ & $\mathrm{C}$ & UUC & A & A & A & $\mathrm{U}$ & $\mathrm{C}$ & $\mathrm{C}$ & $\mathrm{C}$ & $\mathrm{U}$ & G & A & $\mathrm{U}$ & G & $\mathrm{C}$ \\
\hline & CFBP 712 & Burkina Faso & Eggplant & 1 & $2 \mathrm{a}$ & AF207892 & $\mathrm{C}$ & A & G & A & A & $\mathrm{U}$ & $\mathrm{C}$ & UUC & A & G & A & U & $\mathrm{C}$ & C & $\mathrm{C}$ & $\mathrm{U}$ & G & A & $\mathrm{U}$ & G & $\mathrm{C}$ \\
\hline & $\begin{array}{c}\text { NCPPB } \\
1018\end{array}$ & Angola & Potato & 1 & $2 \mathrm{c}$ & AF207893 & $\mathrm{U}$ & A & G & A & A & $\mathrm{C}$ & C & UCU & A & G & A & $\mathrm{U}$ & $\mathrm{C}$ & C & $\mathrm{C}$ & $\mathrm{U}$ & G & A & $\mathrm{U}$ & G & $\mathrm{C}$ \\
\hline & CFBP 2146 & $\begin{array}{l}\text { Reunion } \\
\text { Island }\end{array}$ & $\begin{array}{l}\text { Pelargonium } \\
\text { capitatum }\end{array}$ & 1 & $2 \mathrm{c}$ & AF207894 & $\mathrm{U}$ & A & G & A & A & C & $\mathrm{C}$ & UCU & A & G & A & U & $\mathrm{C}$ & C & $\mathrm{C}$ & $\mathrm{U}$ & G & A & $\mathrm{U}$ & G & C \\
\hline & CFBP 734 & Madagascar & Potato & 1 & $2 \mathrm{c}$ & AF207895 & $\mathrm{U}$ & A & G & A & A & C & $\mathrm{C}$ & UCU & A & G & A & $\mathrm{U}$ & $\mathrm{C}$ & $\mathrm{C}$ & $\mathrm{C}$ & $\mathrm{U}$ & G & A & $\mathrm{U}$ & G & $\mathrm{C}$ \\
\hline & NCPPB 342 & Zimbabwe & Tobacco & 1 & $2 \mathrm{c}$ & AF207896 & $\mathrm{U}$ & A & G & A & A & C & $\mathrm{C}$ & UCU & A & G & A & $\mathrm{U}$ & $\mathrm{C}$ & C & $\mathrm{C}$ & $\mathrm{U}$ & G & A & $\mathrm{U}$ & G & $\mathrm{C}$ \\
\hline & $\begin{array}{l}\text { MAFF } \\
211266\end{array}$ & Japan & Tomato & 1 & 1 & AF207897 & $\mathrm{C}$ & A & G & A & A & C & $\mathrm{C}$ & $\mathrm{ACU}$ & $\mathrm{U}$ & G & A & U & $\mathrm{C}$ & C & $\mathrm{C}$ & $\mathrm{C}$ & A & A & C & A & U \\
\hline & R288 & China & Mulberry & 5 & 1 & U27984 & $\mathrm{C}$ & $\mathrm{A}$ & G & A & A & $\mathrm{C}$ & $\mathrm{C}$ & $\mathrm{ACU}$ & $\mathrm{U}$ & G & A & U & $\mathrm{C}$ & C & $\mathrm{C}$ & $\mathrm{C}$ & A & A & $\mathrm{C}$ & A & $\mathrm{U}$ \\
\hline & ACH092 & Australia & Ginger & 4 & 1 & U27985 & $\mathrm{C}$ & A & G & A & G & $\mathrm{C}$ & $\mathrm{C}$ & $\mathrm{ACU}$ & $\mathrm{U}$ & G & A & U & $\mathrm{C}$ & C & $\mathrm{C}$ & $\mathrm{C}$ & A & A & $\mathrm{C}$ & A & $\mathrm{U}$ \\
\hline & ACH0171 & Australia & Eggplant & 3 & 1 & U27986 & $\mathrm{C}$ & A & G & A & A & C & $\mathrm{C}$ & $\mathrm{ACU}$ & $\mathrm{U}$ & G & A & $\mathrm{U}$ & $\mathrm{C}$ & $\mathrm{C}$ & $\mathrm{C}$ & $\mathrm{C}$ & A & A & C & A & $\mathrm{U}$ \\
\hline & R791 & Indonesia & Tomato & 3 & 1 & U27987 & $\mathrm{C}$ & A & G & A & A & C & $\mathrm{C}$ & $\mathrm{ACU}$ & $\mathrm{U}$ & G & A & U & $\mathrm{C}$ & $\mathrm{C}$ & $\mathrm{C}$ & $\mathrm{C}$ & A & A & C & A & $\mathrm{U}$ \\
\hline & CIP365 & Philippines & Potato & 5 & 1 & U28220 & C & $\mathrm{A}$ & G & A & A & $\mathrm{C}$ & $\mathrm{C}$ & $\mathrm{ACU}$ & $\mathrm{U}$ & G & A & U & $\mathrm{C}$ & C & $\mathrm{C}$ & $\mathrm{C}$ & A & A & $\mathrm{C}$ & A & $\mathrm{U}$ \\
\hline & ACH0732 & Australia & Tomato & 2 & 1 & U27983 & $\mathrm{C}$ & A & G & A & A & $\mathrm{U}$ & $\mathrm{C}$ & UCU & G & G & A & U & $\mathrm{C}$ & C & $\mathrm{C}$ & $\mathrm{C}$ & A & A & C & A & $\mathrm{U}$ \\
\hline & $\begin{array}{c}\text { PDDCC } \\
1727\end{array}$ & United States & Tomato & 1 & $2 a$ & U28221 & C & G & G & A & A & $\mathrm{U}$ & $\mathrm{C}$ & UUC & A & G & A & $\mathrm{U}$ & C & C & $\mathrm{C}$ & $\mathrm{U}$ & G & A & $\mathrm{U}$ & G & $\mathrm{C}$ \\
\hline & CIP210 & Brazil & Potato & 1 & $2 a$ & U28222 & $\mathrm{C}$ & A & G & A & A & $\mathrm{U}$ & C & UUC & A & A & A & U & $\mathrm{C}$ & C & $\mathrm{C}$ & $\mathrm{U}$ & G & A & C & G & $\mathrm{C}$ \\
\hline & R207 & Belize & Musa AAB & 1 & $2 \mathrm{a}$ & U28223 & $\mathrm{C}$ & $\mathrm{A}$ & G & A & A & $\mathrm{U}$ & $\mathrm{C}$ & UUC & A & A & A & U & $\mathrm{C}$ & C & $\mathrm{C}$ & $\mathrm{U}$ & G & A & $\mathrm{U}$ & G & $\mathrm{C}$ \\
\hline & ACH0158 & Australia & Potato & 2 & $2 a$ & U28224 & C & A & G & A & A & C & C & UUC & A & A & A & U & $\mathrm{C}$ & C & $\mathrm{C}$ & U & G & A & C & G & $\mathrm{C}$ \\
\hline & $\operatorname{Br} 150$ & $\begin{array}{l}\text { United } \\
\text { Kingdom }\end{array}$ & $\begin{array}{l}\text { Solanum } \\
\text { dulcamara }\end{array}$ & 2 & $2 \mathrm{a}$ & U28225 & $\mathrm{C}$ & A & G & A & A & $\mathrm{C}$ & C & UUC & A & A & A & U & $\mathrm{C}$ & C & $\mathrm{C}$ & $\mathrm{U}$ & G & A & $\mathrm{C}$ & G & $\mathrm{C}$ \\
\hline & CIP238 & Chile & Potato & 2 & $2 \mathrm{a}$ & U28226 & $\mathrm{C}$ & A & G & A & A & C & $\mathrm{C}$ & UUC & A & A & A & U & $\mathrm{C}$ & C & $\mathrm{C}$ & $\mathrm{U}$ & G & A & C & G & $\mathrm{C}$ \\
\hline & CIP10 & Peru & Potato & N2 & $2 \mathrm{a}$ & U28227 & $\mathrm{C}$ & A & G & A & A & $\mathrm{C}$ & $\mathrm{C}$ & UUC & A & A & A & $\mathrm{U}$ & $\mathrm{C}$ & C & $\mathrm{C}$ & U & G & A & $\mathrm{C}$ & G & $\mathrm{C}$ \\
\hline & $\mathrm{R} 483$ & Philippines & Banana & 1 & $2 \mathrm{a}$ & U28228 & $\mathrm{C}$ & $\mathrm{A}$ & G & A & A & $\mathrm{C}$ & $\mathrm{C}$ & UUC & A & A & A & U & $\mathrm{C}$ & U & $\mathrm{C}$ & $\mathrm{U}$ & G & A & $\mathrm{C}$ & G & $\mathrm{C}$ \\
\hline & R634 & Philippines & Banana & 1 & $2 a$ & U28229 & C & A & G & A & A & C & C & UUC & A & A & A & U & $\mathrm{C}$ & U & $\mathrm{C}$ & $\mathrm{U}$ & G & A & C & G & $\mathrm{C}$ \\
\hline & R633 & Philippines & Banana & 1 & $2 \mathrm{a}$ & U28230 & $\mathrm{C}$ & A & G & A & A & $\mathrm{C}$ & $\mathrm{C}$ & UUC & A & A & A & U & $\mathrm{C}$ & U & $\mathrm{C}$ & U & G & A & $\mathrm{C}$ & G & $\mathrm{C}$ \\
\hline & R639 & Philippines & Banana & 1 & $2 \mathrm{a}$ & U28231 & $\mathrm{C}$ & A & G & A & A & $\mathrm{C}$ & $\mathrm{C}$ & UUC & A & A & A & U & $\mathrm{C}$ & U & $\mathrm{C}$ & $\mathrm{U}$ & G & A & $\mathrm{C}$ & G & $\mathrm{C}$ \\
\hline & $\mathrm{R} 780$ & Indonesia & Potato & $\mathrm{N} 2$ & $2 b$ & U28232 & $\mathrm{C}$ & G & G & A & A & C & $\mathrm{C}$ & UUC & A & G & G & C & $\mathrm{C}$ & C & $\mathrm{C}$ & $\mathrm{C}$ & A & A & $\mathrm{C}$ & A & $\mathrm{U}$ \\
\hline & R142 & Indonesia & Clove & 2 & $2 \mathrm{~b}$ & U28233 & C & G & G & A & A & C & C & UUC & A & G & G & $\mathrm{C}$ & $\mathrm{C}$ & C & $\mathrm{C}$ & $\mathrm{C}$ & A & A & C & A & $\mathrm{U}$ \\
\hline \multirow[t]{3}{*}{$\mathrm{BDB}$} & R506 & Indonesia & Banana & & $2 \mathrm{~b}$ & U28234 & C & G & G & A & A & C & C & UUC & A & G & G & C & U & C & $\mathrm{C}$ & C & A & G & C & A & U \\
\hline & $\mathrm{R} 233$ & Indonesia & Banana & & $2 \mathrm{~b}$ & U28235 & $\mathrm{C}$ & G & G & A & A & C & C & UUC & A & G & G & $\mathrm{C}$ & $\mathrm{U}$ & $\mathrm{C}$ & $\mathrm{C}$ & $\mathrm{C}$ & A & G & C & A & $\mathrm{U}$ \\
\hline & R223 & Indonesia & Banana & & $2 \mathrm{~b}$ & U28236 & C & G & G & A & A & $\mathrm{C}$ & $\mathrm{C}$ & UUC & A & G & G & C & $\mathrm{U}$ & C & A & $\mathrm{C}$ & A & G & $\mathrm{C}$ & A & $\mathrm{U}$ \\
\hline \multirow[t]{2}{*}{ P. syzygii } & R001 & Indonesia & Clove & & $2 \mathrm{~b}$ & U28237 & $\mathrm{C}$ & G & $\mathrm{C}$ & - & A & C & G & UUC & A & G & G & C & $\mathrm{C}$ & C & $\mathrm{C}$ & $\mathrm{C}$ & A & A & $\mathrm{C}$ & A & $\mathrm{U}$ \\
\hline & R058 & Indonesia & Clove & & $2 \mathrm{~b}$ & U28238 & C & G & $\mathrm{N}$ & - & A & $\mathrm{C}$ & G & UUC & A & G & G & C & $\mathrm{C}$ & C & $\mathrm{C}$ & $\mathrm{C}$ & A & A & $\mathrm{C}$ & A & $\mathrm{U}$ \\
\hline
\end{tabular}

*Except for the first seven strains, all of these data were described in the study of Taghavi et al. (1996). CIP, International Potato Center, Lima, Peru; ACH, A. C. Hayward, Department of Microbiology, Centre for Bacterial Diversity and Identification, University of Queensland, St Lucia, Australia; PDDCC, Culture Collection of Plant Diseases Division, DSIR, Auckland, New Zealand.

†Escherichia coli numbering (Woese et al., 1983).

this result could be explained by the branch point separating division 1 and subdivision $2 \mathrm{~b}$, which was not as well supported (bootstrap value only $43 \%$ ) as the branch point between subdivisions $2 \mathrm{a}$ and $2 \mathrm{~b}$ (bootstrap value $59 \%$ ) in the study of Taghavi et al. (1996). Moreover, the latter was supported by the dendrogram generated by the STATLAB software (result not shown). The four African biovar 1 strains originating from Angola, Madagascar, Reunion Island and Zimbabwe were included in a new subdivision, which was designated subdivision $2 \mathrm{c}$. The branch point between subdivisions $2 \mathrm{a}$ and $2 \mathrm{c}$ was stable (bootstrap value $79 \%$ ). The three other biovar 1 strains were distributed either into subdivision 2a (strains CFBP 712 and CFBP 1036), containing $R$. solanacearum biovar 1, 2 and N2 strains, or into division 1 (strain MAFF 211266), containing $R$. solanacearum biovars 3, 4 and 5 and a biovar 2 isolate.

As shown in Table 3, comparison of the differences between the seven analysed strains and with existing data gave useful new data. As expected (Taghavi et al., 1996), the major sequence differences between the two divisions were in positions 458-460 (ACU for division 1 and UUC for division 2) and 474 ( $\mathrm{U}$ for division 1 and $\mathrm{A}$ for division 2). However, four African strains were characterized at positions $458-460$ by UCU and so differed from all other isolates, except for one biovar 2 strain, ACH0732. These four African isolates also differed from all other isolates at position 165 where $U$ was substituted for C. The Burkina Faso strain, CFBP 712, was distinguished from the four other African strains particularly at positions 165, 269 and 458-460, and had the same nucleotide sequence as that of the American isolate, CFBP 1036, except at position 649. The sequence of the biovar 1 Japanese strain, MAFF 211266, was different from that of other biovar 1 isolates, especially at positions 458-460, 474, 1424, 1428, 1451, 1456 and 1472, but was not different from that of biovar 3,4 and 5 strains.

\section{DISCUSSION}

Genomic diversity of $R$. solanacearum was evaluated by using different molecular approaches, extending the previous PCR-RFLP analysis of the hrp gene region (Poussier et al., 1999). AFLP and PCR-RFLP analyses led 
to comparable clustering but AFLP revealed more differences in the identification of clonal lines at the infrasubspecific level.

\section{Clustering of the PCR-RFLP and AFLP profiles}

Five PCR products were shown to be specific to $R$. solanacearum, $P$. syzygii and the BDB strains. This result is consistent with many other studies showing the close relationships between these three bacterial taxa (Eden-Green, 1994; Eden-Green \& Sastraatmadja, 1990; Roberts et al., 1990; Seal et al., 1993; Taghavi et al., 1996). Nevertheless, P. syzygii as well as the BDB strains were distinguished from $R$. solanacearum strains since specific PCR-RFLP profiles, including specific restriction patterns, were obtained for these bacteria. To our knowledge, this is the first report of a simple and rapid method for discriminating $R$. solanacearum strains from $P$. syzygii and the BDB strains. New PCR-RFLP profiles were also obtained with new strains of $R$. solanacearum, particularly biovar $\mathrm{N} 2$ and 5 isolates. Biovar N2 strains generated five different subclusters demonstrating and confirming that biovar $\mathrm{N} 2$ is a genetically heterogeneous group of strains (Cook \& Sequeira, 1994; Gillings \& Fahy, 1994). Notably, the very similar biovars 2 and N2 (Hayward et al., 1990) showed a polymorphism within the RS80-RS81 amplified fragment spanning the $h r p B$ regulatory gene (Genin et al., 1992). Since other groups of $R$. solanacearum strains are distinguishable by polymorphism in this gene (Poussier et al., 1999), the hrpB gene may be considered as a target for further phylogeny purposes, and for relating pathogenicity gene function with genetic variability. The PCR-RFLP and AFLP profiles were distributed into clusters which agreed well with biovar and geographical origin classifications, confirming the results obtained in the previous investigation (Poussier et al., 1999). In addition, this clustering was conserved using two different software packages which use different genetic distance methods, underlining its robustness. Biovar 1 and biovar 2 strains displayed the highest and the lowest diversity, respectively. Biovar 3 strains showed lower genetic diversity than biovar 1 strains. AFLP allowed very fine discrimination, close to the strain level, and reliable determination of genetic relationships between strains. This result is consistent with many previous investigations showing the usefulness of the AFLP procedure in strain identification, and for epidemiology and phylogeny purposes (Aarts et al., 1998; Arias et al., 1997; Blears et al., 1998; Clerc et al., 1998; Folkertsma et al., 1996; Hermans et al., 1995; Janssen et al., 1996, 1997; Keim et al., 1997; Lin et al., 1996; Restrepo et al., 1999). The BDB and R. pickettii strains, which showed specific AFLP profiles, could be distinguished from R. solanacearum strains. However, the overall level of polymorphism between these bacterial taxa was low, confirming their close relationship.

\section{AFLP reveals a high level of polymorphism}

The AFLP analysis revealed great variability within $R$. solanacearum since 60 different AFLP fingerprints were observed for the 96 strains. Thus, with 60 AFLP fingerprints $(95 \%$ of fragments were polymorphic), AFLP has a higher resolution level for intraspecific differentiation of $R$. solanacearum strains than PCRRFLP (20 profiles for 178 strains tested) and RFLP (46 profiles for 164 strains tested) (Cook et al., 1989, 1991; Cook \& Sequeira, 1994). Several DNA fragments were common to all $R$. solanacearum species. Other DNA fragments could distinguish the divisions defined by Cook et al. (1989) within R. solanacearum species or differentiate strains according to their biovar or geographical origin and are therefore useful for the development of diagnostic tools and epidemiological studies. Although AFLP clustering was approximately the same as PCR-RFLP clustering, the AFLP procedure was more efficient for assessing intraspecific diversity since it permitted a clearer separation between biovar 2 and $\mathrm{N} 2$ and also between biovars 3,4 and 5. AFLP and PCR-RFLP confirmed that biovar 2 strains are the least genetically diverse of all biovars (Cook et al., 1989; Cook \& Sequeira, 1994; Smith et al., 1995; Van der Wolf et al., 1998); nevertheless AFLP, in contrast to PCR-RFLP, demonstrated genetic diversity among biovar 2 strains. In contrast, PCR-RFLP permitted strains isolated from musaceous plants to be grouped into two main clusters whereas AFLP grouped them into only one cluster.

\section{New or unexpected groups}

Trees resulting from PCR-RFLP analysis of the hrp gene region, AFLP and 16S rRNA sequencing showed the separation of $R$. solanacearum into two major groups, confirming and extending the conclusions of previous investigations using DNA-DNA hybridization (Palleroni \& Doudoroff, 1971), and more recently of RFLP analyses (Cook et al., 1989, 1991; Cook \& Sequeira, 1994), of PCR amplification with tRNA consensus (Seal et al., 1992), of 16S rRNA sequencing (Li et al., 1993; Taghavi et al., 1996), and of sequencing of the 16S-23S rRNA gene spacer region, the endoglucanase gene and the polygalacturonase gene (Fegan et al., 1998). The first division, named 'Americanum' by Cook et al. (1989), includes biovars 1, 2 and N2; and the second division named 'Asiaticum' contains biovars 3, 4 and 5 .

However, our analyses revealed that there are numerous exceptions. Indeed, our extended PCR-RFLP analysis showed that an African biovar 1 strains group was associated with the 'Asiaticum' division rather than the 'Americanum' division, and so supported the conclusion of the first PCR-RFLP analysis (Poussier et al., 1999). The conclusions of AFLP and 16S rRNA sequencing were different to those of PCR-RFLP and appeared to be in complete agreement with the classification scheme proposed by Cook et al. (1989). Indeed, biovar 1 strains originating from the Southern part of Africa (Angola, Madagascar, Reunion Island, Zimbabwe) appeared to be more closely related to American strains even though they constituted a clearly separable group from American biovar 1 strains, and these were thus included in subdivision $2 \mathrm{c}$, a new 
subdivision compared to the work of Taghavi et al. (1996). The differentiation between American and African biovar 1 strains is more remarkable within the brp gene region (PCR-RFLP analysis). To further clarify whether the discrimination between these two biovar 1 populations is clearer using regions of the genome involved in pathogenicity, other genes such as those encoding endoglucanase or polygalacturonase should be sequenced. The most probable explanation for the distinction between African and American biovar 1 isolates is separate evolution of the two populations due to geographical isolation. The two populations may have diverged under different natural selection pressures. The observation that other African isolates (three coming from Burkina Faso and one from Kenya) fell into clusters containing only American members may result from their introduction from the Americas through commercial exchanges.

The Japanese strains, MAFF 211266 and MAFF 211267 , confirmed to be biovar 1 in our laboratory, were considered to be atypical. Both PCR-RFLP analysis and $16 \mathrm{~S}$ rRNA sequence analysis indicated that these Japanese isolates appeared to be closely related to strains belonging to the 'Asiaticum' division, confirming the findings of Tsuchiya \& Horita (1998). The peculiarity of these strains, which underlines the level of heterogeneity existing in the $R$. solanacearum species, may result from horizontal genetic transfers from biovar 3 or 4 members, which predominate in Japan. Moreover, another Japanese strain, MAFF 301558, was also unusual since PCR-RFLP and AFLP analyses showed that this biovar $\mathrm{N} 2$ strain was distantly related to all other biovar N2 strains and closely related to biovars 3, 4 and 5. This is not the first report of atypical isolates since $\mathrm{Li} \&$ Hayward (1994) and Taghavi et al. (1996) also mentioned one atypical (ACH0732) biovar 2 strain. Furthermore, the two strains JT510 and JQ1056, which were identified as biovar 2 on several independent examinations, were unusual in AFLP grouping. It is possible that limited genomic rearrangements or genetic exchanges which do not modify the biovar typing occur. These considerations reinforce the need for a classification system that is based upon polymorphism between genes encoding pathogenicity functions. This would in turn permit more meaningful comparisons with specific phenotypic characteristics such as host specificity and survival in natural settings to be made.

Clearly the species $R$. solanacearum comprises two divisions, which may represent subspecies as suggested by Li et al. (1993). However, the 'Americanum' and 'Asiaticum' designations of these divisions proposed by Cook et al. (1989) in relation to the presumed geographical origin of strains could be reconsidered since our analyses reveal an African biovar 1 subdivision, which may have its own centre of genetic diversity, and thus likely evolutionary origin, in Africa.

\section{ACKNOWLEDGEMENTS}

We are grateful to Nigel Grimsley for reviewing the manuscript and all colleagues that have contributed strains to this study. This work was supported in part by a grant from the Ministère de l'Enseignement Supérieur et de la Recherche.

\section{REFERENCES}

Aarts, H. J. M., Van Lith, L. A. J. T. \& Keijer, J. (1998). Highresolution genotyping of Salmonella strains by AFLP-fingerprinting. Lett Appl Microbiol 26, 131-135.

Arias, C. R., Verdonck, L., Swings, J., Garay, E. \& Aznar, R. (1997). Intraspecific differentiation of Vibrio vulnificus biotypes by amplified fragment length polymorphism and ribotyping. Appl Environ Microbiol 63, 2600-2606.

Ausubel, F. M., Brent, R., Kingston, R. E., Moore, D. D., Seidman, J. G., Smith, J. A. \& Struhl, K. (1991). Current Protocols in Molecular Biology. New York: Greene Publishing AssociatesWiley Interscience.

Blears, M. J., De Grandis, S. A., Lee, H. \& Trevors, J. T. (1998). Amplified Fragment Length Polymorphism (AFLP): a review of the procedure and its application. J Ind Microbiol Biotechnol 21, 99-114.

Buddenhagen, I., Sequeira, L. \& Kelman, A. (1962). Designation of races in Pseudomonas solanacearum. Phytopathology 52, 726.

Clerc, A., Manceau, C. \& Nesme, X. (1998). Comparison of randomly amplified polymorphic DNA with amplified fragment length polymorphism to assess genetic diversity and genetic relatedness within Genospecies III of Pseudomonas syringae. Appl Environ Microbiol 64, 1180-1187.

Cook, D. \& Sequeira, L. (1994). Strain differentiation of Pseudomonas solanacearum by molecular genetics methods. In Bacterial Wilt: the Disease and its Causative Agent, Pseudomonas solanacearum, pp. 77-93. Edited by A. C. Hayward \& G. L. Hartman. Wallingford: CAB International.

Cook, D., Barlow, E. \& Sequeira, L. (1989). Genetic diversity of Pseudomonas solanacearum: detection of restriction fragment length polymorphisms with DNA probes that specify virulence and the hypersensitive response. Mol Plant-Microbe Interact 2, 113-121.

Cook, D., Barlow, E. \& Sequeira, L. (1991). DNA probes as tools for the study of host-pathogen evolution: the example of Pseudomonas solanacearum. In Advances in Molecular Genetics of Plant-Microbe Interactions, pp. 103-108. Edited by $\mathrm{H}$. Henneke \& D. P. S. Verma. Dordrecht: Kluwer.

Eden-Green, S. J. (1994). Diversity of Pseudomonas solanacearum and related bacteria in South East Asia: new direction for moko disease. In Bacterial Wilt: the Disease and its Causative Agent, Pseudomonas solanacearum, pp. 25-34. Edited by A. C. Hayward \& G. L. Hartman. Wallingford: CAB International.

Eden-Green, S. J. \& Sastraatmadja, H. (1990). Blood disease present in Java. FAO Plant Protein Bull 38, 49-50.

Fegan, M., Taghavi, M., Sly, L. I. \& Hayward, A. C. (1998). Phylogeny, diversity and molecular diagnostics of Ralstonia solanacearum. In Bacterial Wilt Disease: Molecular and Ecological Aspects, pp. 19-33. Edited by P. Prior, C. Allen \& J. Elphinstone. Paris: INRA Editions.

Felsenstein, J. (1985). Confidence limits on phylogenies: an approach using the bootstrap. Evolution 39, 783-791.

Felsenstein, J. (1995). PHYLIP (phylogeny inference package), version 3.55. Seattle: Department of Genetics, University of Washington.

Folkertsma, R. T., Rouppe Van der Voort, J. N. A. M., de Groot, K. E., Van Zandvoort, P. M., Schots, A., Gommers, F. J., Helder, J. \& Bakker, J. (1996). Gene pool similarities of potato cyst nematode 
populations assessed by AFLP analysis. Mol Plant-Microbe Interact 9, 47-54.

Genetics Computer Group (1999). Wisconsin package, version 10.0. Madison, WI: Genetics Computer Group.

Genin, S., Gough, C. L., Zischek, C. \& Boucher, C. A. (1992). Evidence that the $h r p \mathrm{~B}$ encodes a positive regulator of pathogenicity genes from Pseudomonas solanacearum. Mol Microbiol 6, 3065-3076.

Gillings, M. R. \& Fahy, P. (1994). Genomic fingerprinting: towards a unified view of the Pseudomonas solanacearum species complex. In Bacterial Wilt: the Disease and its Causative Agent, Pseudomonas solanacearum, pp. 95-112. Edited by A. C. Hayward \& G. L. Hartman. Wallingford: CAB International.

Hayward, A. C. (1964). Characteristics of Pseudomonas solanacearum. J Appl Bacteriol 27, 265-277.

Hayward, A. C. (1991). Biology and epidemiology of bacterial wilt caused by Pseudomonas solanacearum. Annu Rev Phytopathol 29, 65-87.

Hayward, A. C., El-Nashaar, H. M., Nydegger, U. \& De Lindo, L. (1990). Variation in nitrate metabolism in biovars of Pseudomonas solanacearum. J Appl Bacteriol 69, 269-280.

He, L. Y., Sequeira, L. \& Kelman, A. (1983). Characteristics of strains of Pseudomonas solanacearum. Plant Dis 67, 1357-1361.

Hermans, P. W. M., Sluijter, M., Hoogenboezem, T., Heersma, H., Vanbelkum, A. \& De Groot, R. (1995). Comparative study of five different DNA fingerprint techniques for molecular typing of Streptococcus pneumoniae strains. J Clin Microbiol 33, 1606-1612.

Janssen, P., Coopman, R., Huys, G., Swings, J., Bleeker, M., Vos, P., Zabeau, M. \& Kersters, K. (1996). Evaluation of the DNA fingerprinting method AFLP as a new tool in bacterial taxonomy. Microbiology 142, 1881-1893.

Janssen, P., Maquelin, K., Coopman, R., Tjernberg, I., Bouvet, P., Kersters, K. \& Dijkshoorn, L. (1997). Discrimination of Acinetobacter genomic species by AFLP fingerprinting. Int J Syst Bacteriol 47, 1179-1187.

Jukes, T. H. \& Cantor, C. R. (1969). Evolution of protein molecules. In Mammalian Protein Metabolism, vol. 3, pp. 21-132. Edited by H. N. Munro. New York: Academic Press.

Keim, P., Kalif, A., Schupp, J. \& 7 other authors (1997). Molecular evolution and diversity in Bacillus anthracis as detected by amplified fragment length polymorphism markers. J Bacteriol 179, 818-824.

Li, X., Dorsch, M., Del Dot, T., Sly, L. I., Stackebrandt, E. \& Hayward, A. C. (1993). Phylogenetic studies of the rRNA group II pseudomonads based on $16 \mathrm{~S}$ rRNA gene sequences. J Appl Bacteriol 74, 324-329.

Li, X. \& Hayward, A. C. (1994). Bacterial whole cell protein profiles of the rRNA group II pseudomonads. J Appl Bacteriol 77, 308-318.

Lin, J.-J., Kuo, J. \& Ma, J. (1996). A PCR-based DNA fingerprinting technique: AFLP for molecular typing of bacteria. Nucleic Acids Res 24, 3649-3650.

Nei, M. (1973). Analysis of gene diversity in subdivided populations. Proc Natl Acad Sci 70, 3321-3323.

Palleroni, N. J. \& Doudoroff, M. (1971). Phenotypic characterization and deoxyribonucleic acid homologies of Pseudomonas solanacearum. J Bacteriol 107, 690-696.
Pegg, K. \& Moffett, M. (1971). Host range of the ginger strain of Pseudomonas solanacearum in Queensland. Aust J Exp Agric Anim Husb 11, 696-698.

Poussier, S., Vandewalle, P. \& Luisetti, J. (1999). Genetic diversity of African and worldwide strains of Ralstonia solanacearum as determined by PCR-Restriction Fragment Length Polymorphism analysis of the hrp gene region. Appl Environ Microbiol 65, 2184-2194.

Restrepo, S., Duque, M., Tohme, J. \& Verdier, V. (1999). AFLP fingerprinting: an efficient technique for detecting genetic variation of Xanthomonas axonopodis pv. manihotis. Microbiology 145, 107-114.

Roberts, S. J., Eden-Green, S. J., Jones, P. \& Ambler, D. J. (1990). Pseudomonas syzygii sp. nov., the cause of Sumatra disease of cloves. Syst Appl Microbiol 13, 34-43.

Seal, S. E., Jackson, L. A. \& Daniels, M. J. (1992). Use of tRNA consensus primers to indicate subgroups of Pseudomonas solanacearum by polymerase chain reaction amplification. Appl Environ Microbiol 58, 3759-3761.

Seal, S. E., Jackson, L. A., Young, J. P. W. \& Daniels, M. J. (1993). Differentiation of Pseudomonas solanacearum, Pseudomonas syzygii, Pseudomonas pickettii and the Blood Disease Bacterium by partial $16 \mathrm{~S}$ rRNA sequencing: construction of oligonucleotide primers for sensitive detection by polymerase chain reaction. $J$ Gen Microbiol 139, 1587-1594.

Smith, J. J., Offord, L. C., Holderness, M. \& Saddler, G. S. (1995). Genetic diversity of Burkholderia solanacearum (synonym Pseudomonas solanacearum) race 3 in Kenya. Appl Environ Microbiol 61, 4263-4268.

Sneath, P. H. A. \& Sokal, R. R. (1973). Numerical Taxonomy: the Principles and Practice of Numerical Classification. San Francisco: W. H. Freeman.

Taghavi, M., Hayward, C., Sly, L. I. \& Fegan, M. (1996). Analysis of the phylogenetic relationships of strains of Burkholderia solanacearum, Pseudomonas syzygii, and the Blood Disease Bacterium of banana based on $16 \mathrm{~S}$ rRNA gene sequences. Int J Syst Bacteriol 46, 10-15.

Tsuchiya, K. \& Horita, M. (1998). Genetic diversity of Ralstonia solanacearum in Japan. In Bacterial Wilt Disease: Molecular and Ecological Aspects, pp. 61-73. Edited by P. Prior, C. Allen \& J. Elphinstone. Paris: INRA Editions.

Van der Wolf, J. M., Bonants, P. J. M., Smith, J. J., Hagenaar, M., Nijhuis, E., Van Beckhoven, J. R. C. M., Saddler, G. S., Trigalet, A. \& Feuillade, R. (1998). Genetic diversity of Ralstonia solanacearum race 3 in Western Europe determined by AFLP, RCPFGE and Rep-PCR. In Bacterial Wilt Disease: Molecular and Ecological Aspects, pp. 44-49. Edited by P. Prior, C. Allen \& J. Elphinstone. Paris: INRA Editions.

Vos, P., Hogers, R., Bleeker, M. \& 8 other authors (1995). AFLP: a new technique for DNA fingerprinting. Nucleic Acids Res 23, 4407-4414.

Ward, J. H. (1963). Hierarchical grouping to optimize an objective function. Am Stat Assoc J 58, 236-244.

Woese, C. R., Gutell, R., Gupta, R. \& Noller, H. F. (1983). Detailed analysis of the higher-order structure of 16S-like ribosomal ribonucleic acids. Microbiol Rev 47, 621-669.

Received 2 December 1999; revised 1 March 2000; accepted 27 March 2000. 